\title{
Chancriform penile cutaneous leishmaniasis
}

\section{Fatma Frikha, Emna Bahloul, Abderrahmen Masmoudi, Meriem Amouri, Hamida Turki}

Department of Dermatology, Hedi Chaker Hospital, Sfax Tunisia

Corresponding author: Dr. Fatma Frikha, E-mail: frikhafat@gmail.com

Sir,

Cutaneous leishmaniasis (CL) is endemic in Tunisia, particularly in the central and northern parts of the country. CL is more frequently seen on exposed body areas such as the face, eyelids, forehead, hands, wrists and, occasionally, the legs. The involvement of the penis is unusual.

A 42-year-old man from southern Tunisia presented to the dermatology department with a 2 month history of asymptomatic and persistent ulcer on his penis. He was taking no medications. The patient's general medical and specific sexual history was unremarkable. Physical examination showed a $2 \times 1,5 \mathrm{~cm}$ ulcer with a slightly indurated base and raised infiltrative borders on the glans, adjacent to a second $0,5 \mathrm{~cm}$ ulceration (Fig. 1). The rest of the examination was unremarkable. Smears, taken from both lesions, showed Leishmania amastigotes. Polymerase-chain-reaction (PCR) assay identified Leishmania Major. The diagnosis of chancriform CL was confirmed. No regional lymph nodes were noted.

The patient was treated with meglumine antimoniate intramuscular $(60 \mathrm{mg} / \mathrm{kg} / \mathrm{day})$ during three weeks; with complete cicatrization of the lesions and indelible scars.

Our observation was specific by the unusual localization of the CL and by the clinical form. The involvement of the penis is rare, although there are a few previous reports $[1,2]$.

The peak of nocturnal activity of Phlebotomus and the habit of sleeping naked may explain the emergence of cases of CL in the genital area [3]. A more detailed anamnesis in our patient revealed an insect bite on the glans some weeks prior to the ulceration.

Cutaneous leishmaniasis should be considered for lesions that do not heal for a long time in individuals who live or travel to regions that have a high risk of

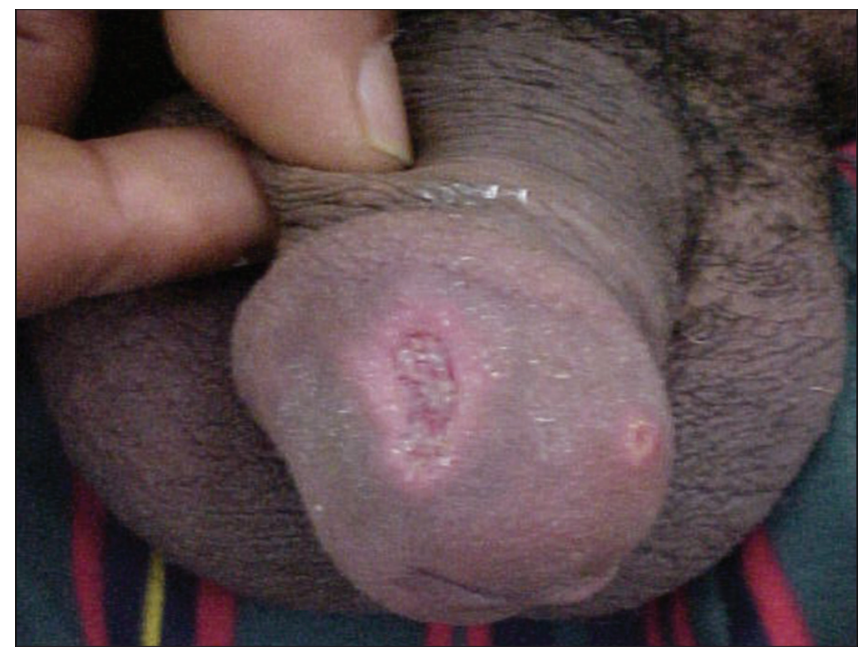

Figure1: Figure 1: Two ulcerations with a slightly indurated base and raised infiltrative borders on the glans.

CL, no matter whether lesions are located in covered or non-covered areas.

\section{Consent}

The examination of the patient was conducted according to the Declaration of Helsinki principles.

\section{REFERENCES}

1. Schubach A, Cuzzi-Maya T, Gonçalves-Costa SC, Pirmez C, Oliveira-Neto MP. Leishmaniasis of glans penis. J Eur Acad Dermatol Venereol. 1998;10:226-8.

2. Yesilova Y, Turan E, Sürücü H, Kocarslan S, Tanrikulu O, Eroglu N. Ulcerative penile leishmaniasis in a child. Indian J Dermatol Venereol Leprol. 2014;80:247.

3. Herbert VG, Böer-Auer A, Brandenburg A, Falk TM, Reiter-Owona I, Rockstroh JK, et al. Severe ulcerative penile leishmaniasis - Importance of PCR-based diagnostics. J Infect. 2015;71:139-41.

Copyright by Fatma Frikha, et al. This is an open-access article distributed under the terms of the Creative Commons Attribution License, which permits unrestricted use, distribution, and reproduction in any medium, provided the original author and source are credited.

Source of Support: Nil, Conflict of Interest: None declared.

\footnotetext{
How to cite this article: Frikha F, Bahloul E, Masmoudi A, Amouri M, Turki H. Chancriform penile cutaneous leishmaniasis. Our Dermatol Online. 2020;11(1):94. Submission: 29.07.2019; Acceptance: 02.10.2019

DOI: 10.7241 /ourd.20201.29
} 